\title{
Glacier changes from 1966-2009 in the Gongga Mountains, on the south-eastern margin of the Qinghai-Tibetan Plateau and their climatic forcing
}

\author{
B. T. Pan, G. L. Zhang, J. Wang, B. Cao, H. P. Geng, J. Wang, C. Zhang, and Y. P. Ji \\ Key Laboratory of Western China's Environmental Systems (Ministry of Education), Lanzhou University, \\ Lanzhou 730000, China \\ Correspondence to: G. L. Zhang (guoliang.zhang@126.com)
}

Received: 21 November 2011 - Published in The Cryosphere Discuss.: 20 December 2011

Revised: 3 July 2012 - Accepted: 29 August 2012 - Published: 2 October 2012

\begin{abstract}
In order to monitor the changes of the glaciers in the Gongga Mountain region on the south-eastern margin of the Qinghai-Tibetan Plateau, 74 monsoonal temperate glaciers were investigated by comparing the Chinese Glacier Inventory (CGI), recorded in the 1960s, with Landsat MSS in 1974, Landsat TM in 1989, 1994, 2005, and ASTER data in 2009. The remote sensing data have been applied to map the glacier outline by threshold ratio images (TM4/TM5). Moreover, the glacier outlines were verified by GPS survey on four large glaciers (Hailuogou (HLG), Mozigou (MZG), Yanzigou (YZG), and Dagongba (DGB)) in 2009. The results show that the area dominated by the 74 glaciers has shrunk by $11.3 \%\left(29.2 \mathrm{~km}^{2}\right)$ from 1966 to 2009 . Glacier area on the eastern and western slopes of the Gongga Mountains decreased by $9.8 \%$ and $14.6 \%$ since 1966 , respectively. The loss in glacier area and length is, respectively, $0.8 \mathrm{~km}^{2}$ and $1146.4 \mathrm{~m}$ for the HLG Glacier, $2.1 \mathrm{~km}^{2}$ and $501.8 \mathrm{~m}$ for the MZG Glacier, $0.8 \mathrm{~km}^{2}$ and $724.8 \mathrm{~m}$ for the YZG Glacier, and $2.4 \mathrm{~km}^{2}$ and $1002.3 \mathrm{~m}$ for the DGB Glacier. Decades of climate records obtained from three meteorological stations in the Gongga Mountains were analyzed to evaluate the impact of the temperature and precipitation on glacier retreat. The mean annual temperatures over the eastern and western slopes of the Gongga Mountains have been increasing by $0.34 \mathrm{~K} \mathrm{decade}^{-1}$ and $0.24 \mathrm{Kdecade}^{-1}(1988-2009)$, respectively. Moreover, mean annual precipitation has only increased by $1 \%$ in the past $50 \mathrm{yr}$. The increasing amount of precipitation could not compensate for the glacier mass loss due to the temperature increase in the Gongga Mountains. This suggests that the warming of the climate is probably
\end{abstract}

also responsible for the glacier retreat in the study region. At the region scale, glacier changes were also controlled by local topographical factors.

\section{Introduction}

Glaciers are a critical component of the Earth system and the present accelerated melting and retreat of glaciers has severe impacts on the environment and human well-being, including vegetation patterns, economic livelihood, natural disasters, and water-energy supplies (UNEP, 2007). Changes in glacier extent in mountainous regions are widely recognized as one of the best natural indicators of global climate change (Oerlemans, 1994, 2005), and the decline in glacier extent in mountains and other regions contributes to sea level rise (Arendt et al., 2002; Larsen et al., 2007; Schiefer et al., 2007). The area and length change of a glacier in response to climate change depends on its geometry and climatic setting (Oerlemans, 2005). Extensive meteorological experiments on glaciers have shown that the primary source for melt energy is solar radiation but that fluctuations in the mass balance through the years are mainly due to temperature and precipitation (Oerlemans, 2005; Greuell and Smeets, 2001; Ohmura, 2001). Recently, many global scale records of glacier change have been obtained through field investigation, ground and aerial photographic measurements, and high-resolution remote sensing (Barry, 2006; DeBeer and Sharp, 2007; Racoviteanu et al., 2008; Paul and Andreassen, 2009; Shangguan et al., 2007; Aizen et al., 2006; Kääb, 2005;

Published by Copernicus Publications on behalf of the European Geosciences Union. 
Liu et al., 2006). These studies indicate the general trend of glacier recession with only a few glaciers advancing. The monsoonal temperate glaciers, with high accumulation and ablation rates and large mass-balance fluctuations (Braithwaite and Zhang, 2000; Kaser et al., 2006), are more active than cold and continental glaciers, and thus more sensitive to the changing climate (Oerlemans and Fortuin, 1992; Fujita and Ageta, 2000; Fujita, 2008).

In China, numerous glaciers exist within and around the Qinghai-Tibetan Plateau. Established in the 1960s, the first Chinese Glacier Inventory (CGI) was compiled from aerial photography, and formed a significant step in integrating knowledge of glaciers in China (Shangguan et al., 2006). The data were subsequently abridged into a Concise CGI and published in both Chinese and English to make the inventory more accessible (Shi et al., 2009). In order to gather accurate information on glacier status for the 30-40 yr after the first Chinese Glacier Inventory and in response to the USGS-led GLIMS (Global Land Ice Measurements from Space) project (Kargel et al., 2005), the new Chinese Glacier Inventory was started in 2006 using new multi-spectral satellite data with a high spatial resolution.

Glacier changes in the Gongga Mountains have been recorded since the 1930s (e.g. Heim, 1936; Anderson, 1939). Cui (1958) reported comprehensive information on the glaciers in the Gongga Mountains. More recently, Su et al. (1992) presented new data on glacier changes based on field investigations, including repeated survey expeditions to the Qinghai-Tibetan Plateau by the Chinese Academy of Sciences (1981-1983) and the Sino-Soviet joint glaciological expedition to the Gongga Mountains in 1990 (Aizen et al., 1994). More glacier parameters in the Gongga Mountains were measured by $\mathrm{Pu}$ (1994), based on a topographic map derived from aerial photographs acquired in the 1960s. Using the equilibrium line altitude method, assuming mean specific balance is zero $\left(\mathrm{ELA}_{0}\right)$, and observed melting data, Xie et al. (2001) discovered that the mass-balance in Hailuogou (HLG) Glacier (one of the largest glaciers in the Gongga Mountain) was about $-488 \mathrm{~mm} \mathrm{yr}^{-1}$ from 1990 to 1998, and attributed this to an increase in ablation. GPS surveys showed that the elevation of the HLG Glacier's ablation zone was lowering at a rate of $1.1 \pm 0.4 \mathrm{~m} \mathrm{yr}^{-1}$ from 1966 to 2009 (Zhang et al., 2010). The study on the relation between HLG Glacier shrinkage and hydrological response showed increasing storage loss during the last $20 \mathrm{yr}$ (Liu et al., 2010).

In the longer term, $\mathrm{Li}$ et al. (2010a) found that the HLG glacier retreated considerably in the warm climate of the middle Holocene, and advanced three times during the Neoglacial and three times during the Little Ice Age in response to cold periods. However, most of this research has focused on a single glacier in the Gongga Mountains, with little consideration of the changes in length and area of all glaciers in the Gongga Mountains. Using multi-temporal remote sensing data in different periods, including Landsat MSS (Multispectral Scanner), TM, ETM+

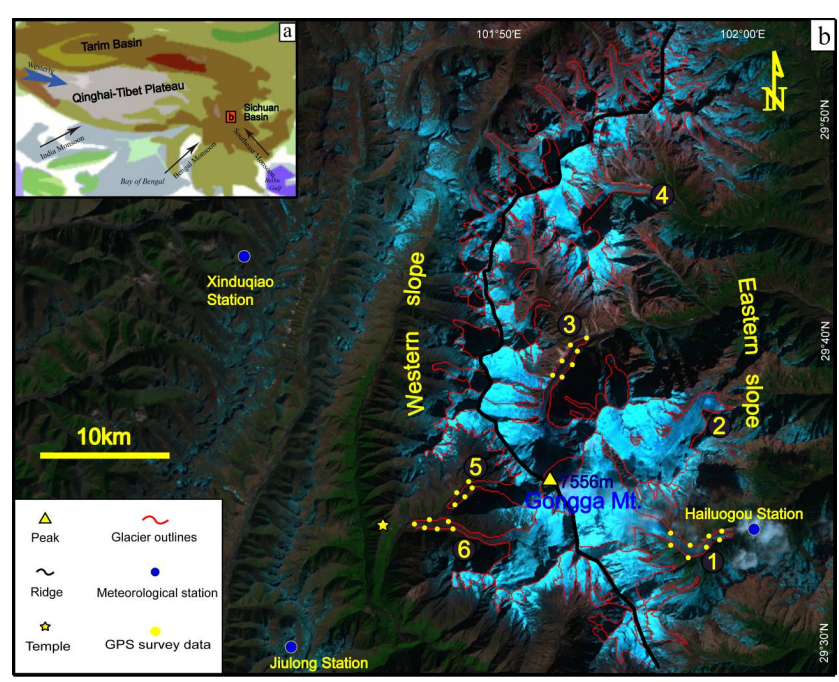

Fig. 1. The location of Gongga Mountains (a) Showing the location of the Study region; Jiulong and Xinduqiao meteorological stations; (b) Glacier extent in Study region with Landsat TM band 743 (as RGB): NO.1 Hailuogou Glacier, NO.2 Mozigou Glacier, NO.3 Yanzigou Glacier, NO.4 Nanmenguangou Glacier, NO.5 Xiaogongba Glacier and NO.6 Dagongba Glacier. Yellow point is a sketch about GPS data.

(Thematic Mapper Plus), ASTER (Advanced Spaceborne Thermal Emission and Reflection) and CGI data based on topographic maps derived from aerial photographs, this study attempts to investigate changes of all glaciers in the Gongga Mountains since the $1960 \mathrm{~s}$, and to identify the drivers for these changes, especially in terms of global climate change.

\section{Study area}

The Gongga Mountains $\left(29^{\circ} 20^{\prime}-30^{\circ} 10^{\prime} \mathrm{N}, \quad 101^{\circ} 30^{\prime}-\right.$ $102^{\circ} 10^{\prime} \mathrm{E}$ ) are situated on the south-eastern margin of the Qinghai-Tibet Plateau (Fig. 1); the highest peak (Mount Gongga) has an elevation of $7556 \mathrm{~m}$ a.s.l. Geomorphologically, the Gongga Mountains are located at the transition zone between the Sichuan Basin and the Qinghai-Tibet Plateau and climatically between the warm-wet monsoon climatic region of the eastern subtropics and cold-dry region of the Qinghai-Tibet Plateau. The climate of the Gongga Mountains is not only controlled by the Southern and Eastern Asia monsoons, but also the Qinghai-Tibet plateau monsoon and the westerly circulation ( $\mathrm{Li}$ et al., 2010b). The annual precipitation is $\sim 1871 \mathrm{~mm}$ at $3000 \mathrm{~m}$ a.s.l. on the eastern slope of the Gongga Mountains and $\sim 1173 \mathrm{~mm}$ at $3700 \mathrm{~m}$ a.s.l. on the western slope ( $\mathrm{Su}$ et al., 1992). The mean annual air temperature is $3.7^{\circ} \mathrm{C}$ on the eastern slope ( $3000 \mathrm{~m}$ a.s.l.) and only $1.9^{\circ} \mathrm{C}$ on the western slope (3700 ma.s.1.) (Su et al., 1992). The climatic equilibrium line altitude (ELA) (a multi-year average of ELA on a bare planar surface; Shi, 1988) is about $4900 \mathrm{~m}$ on the eastern 
Table 1. Data sources used in this study.

\begin{tabular}{llllll}
\hline Image & Path/row & Date & Resolution or scale & Cloud cover & Source \\
\hline Topographic map & - & 1971 & $1: 100000$ & - & Chinese military geodetic service \\
DEM & - & 1989 & $20 \mathrm{~m}$ or $1: 50000$ & - & Topographic map \\
CGI & - & 1966 & $1: 100000$ & - & Aerial photographs \\
Landsat 2 MSS & $140 / 39$ & $1974 / 01 / 21$ & $80 \mathrm{~m}$ & $0 \%$ & USGS/NASA \\
Landsat 5 TM & $131 / 39$ & $1989 / 01 / 02$ & $30 \mathrm{~m}$ & $0 \%$ & USGS/NASA \\
Landsat 5 TM & $131 / 39$ & $1994 / 09 / 05$ & $30 \mathrm{~m}$ & $0 \%$ & USGS/NASA \\
Landsat 5 TM & $131 / 39$ & $2005 / 02 / 07$ & $30 \mathrm{~m}$ & $11 \%$ & USGS/NASA \\
Landsat 7 ETM+ & $131 / 39$ & $2002 / 01 / 06$ & $30 \mathrm{~m}$ & $0 \%$ & USGS/NASA \\
Terra ASTER & - & $2009 / 05 / 23$ & $15 \mathrm{~m}$ & $3 \%$ & NASA /METI \\
\hline
\end{tabular}

slope and about $5100 \mathrm{~m}$ on the western slope ( $\mathrm{Su}$ et al., 1992). The altitudinal gradient of temperature described by $\mathrm{Su}$ et al. (1993) from field observation was $-2.3^{\circ} \mathrm{C} \mathrm{km}^{-1}$, $-9{ }^{\circ} \mathrm{C} \mathrm{km}^{-1}$ and $-2{ }^{\circ} \mathrm{C} \mathrm{km}^{-1}$ on the altitudinal belt 2880 $3010 \mathrm{~m}, 3010-3210 \mathrm{~m}$ and $3210-3510 \mathrm{~m}$, respectively. Su et al. (1993) and Gao and Peng (1994) indicated that the western slope has two rainfall zones - the first is between $3700 \mathrm{~m}$ and $3900 \mathrm{~m}$ a.s.1., the second is between $4900 \mathrm{~m}$ and $6000 \mathrm{~m}$ a.s.l.; the eastern slope also has two rainfall zones the first is between $2900 \mathrm{~m}$ and $3400 \mathrm{~m}$ a.s.l., the second is above $5000 \mathrm{~m}$ a.s.1.

According to the CGI $(\mathrm{Pu}, 1994)$, this region has 74 glaciers with a total area of $257.7 \mathrm{~km}^{2}$, including five valley glaciers with lengths of more than $10 \mathrm{~km}$ : the HLG, MZG, YZG, Nanmenguangou (NMGG) Glaciers on the eastern slope and the DGB Glacier on the western slope. The glaciers in this region are classified as summer-accumulation type (Su et al., 1996; Xie et al., 2001), which have more accumulation in summer than winter (Ageta and Higuchi, 1984) and are characterized by high flow velocity, high accumulation and heavy melting. Many moraines are distributed around the glacier snouts, and both terminal and lateral moraines along the western slope are more developed than those along the eastern slope.

\section{Data sources and methods}

\subsection{Data sources}

The changes in the glaciers were determined by comparing glacier area and length from multi-temporal spaceborne imagery, including Landsat MSS, TM, ETM+, ASTER and CGI (Table 1). The glacier outlines from the CGI (Pu, 1994) were interpreted and measured by stereophotogrammetry from aerial photographs at a scale of 1:60000 taken during 1966. The glacier outlines were corrected based on aerial photographs and field investigation ( $\mathrm{Pu}, 1994)$. The error in glacial extent estimates for the first CGI is in the range of $\pm 0.5 \%$ to $\pm 1 \%$ (Pu, 1994; Shi, 2008). As the first CGI is the oldest archive of glacier extents in the west of China (e.g.
Shangguan et al., 2006, 2007, 2009; Liu et al., 2010), we digitized the glacier outlines of the first CGI as vector files and took them as the reference data to analyze later changes in the Gongga Mountains glaciers.

Good quality Landsat MSS/TM/ETM+ scenes were downloaded from USGS (United States Geological Survey) webserver (Table 1). These data include one Landast MSS image (1974), three Landsat TM images (1989, 1994 and 2005) and one Landsat ETM+ image (2002). Two ASTER images (2009) with no clouds and minimal seasonal snowcover were provided by the NASA (National Aeronautics and Space Administration)/METI (Ministry of Economy, Trade and Industry).

A $20 \mathrm{~m}$ resolution digital elevation model (DEM) was constructed from the digitized contours of a 1989 topographic map with a scale of $1: 50000$ and was used to analyze the topographic features of the glaciers (e.g. slope, aspect, elevation). The DEM and glacier extents from the CGI were reprojected onto the Universal Transverse Mercator coordinate system (UTM zone 47N, WGS84) using a seven-parameter datum transformation model (Guo et al., 2002; Wang et al., 2003) following Zhang et al. (2010). The error using a sevenparameter datum transformation model is $<0.002 \mathrm{~m}$ (Wang et al., 2003). To establish co-registration of different images, 30-50 ground-control points (GCPs) were selected from two images. The ASTER image was orthorectified by ENVI 4.6 Automatic Registration package using the Landsat ETM+ image and the DEM and resampled to a $15 \mathrm{~m} \times 15 \mathrm{~m}$ grid size. Twenty independent verification points ( $\mathrm{Li}$ et al., 1998) were selected from each image in order to check the accuracy of co-registration. The residual root mean square error (RMSe), when compared with Landsat ETM+, was usually less than 1.2 pixels $(18 \mathrm{~m})$.

\subsection{Methods}

In this study, automated glacier mapping from multi-spectral satellite data was performed using the band ratio method (Hall et al., 1987). Since the ratio of bands can provide improved contrast (relative to a single band) between glaciers that are surrounded by ablation areas of debris, or till-laden 
glaciers (Hall et al., 1987). The method is widely used in worldwide glacier inventories (Khromova et al., 2003; Paul and Kääb, 2005; Aizen et al., 2006; Raup et al., 2007; Paul and Andreassen, 2009; Svoboda and Paul, 2009).

For glacier ice with very low reflectance in the middle infrared Landsat TM band ratios of TM3/TM5 or TM4/TM5 are often used for glacier mapping (Paul, 2002; Paul and Andreassen, 2009). However, for the 74 glaciers studied in Gongga Mountains, the TM4/TM5 > 2.4 (Table 2) was more effective than TM3/TM5, and an additional threshold in TM1 (DNs > 59) was set to improve glacier mapping in shadow (Paul and Kääb, 2005). This method is simple to apply and the result is accurate for debris-free glaciers (Albert, 2002; Andreassen et al., 2008). Glacier mapping by spectral band combinations (TM3/TM5 or TM4/TM5) is accepted as the most efficient method of mapping debris-free glaciers (Paul, 2002), but it is not suitable for debris-covered glaciers, which are generally mapped manually. Glacier mapping with ASTER was done using threshold band ratio (Table 2) of the third band (red band) and the fourth band (SWIR band), a method that has already been shown to be successful in other regions (e.g. Paul, 2002; Paul and Kääb, 2005; Raup et al., 2007; Svoboda and Paul, 2009). Svoboda and Paul (2009) have discussed glacier mapping with Landsat MSS, and obtained satisfactory results on southern Baffin Island, Canada. We chose their method to extract glacier extent from Landsat MSS. The specific method is as follows: a decision-tree classifier that utilizes multiple thresholds (Table 2) was used because MSS has no SWIR band; instead of a SWIR band, an NIR (near-Infrared) band was used for the band ratio (MSS3/MSS4); and an additional threshold in the first NIR band (MSS3) was applied to remove incorrectly classified rocks in shadow (Svoboda and Paul, 2009).

The image ratio and supervised classification is the most common method to extract glacier borders (Paul et al., 2002, 2004). Due to the limitations of the method (Paul et al., 2002), many debris-covered glaciers in the Gongga Mountains are difficult to extract glacier outlines. In these cases, visual interpretation was applied. Terminal moraine, the head of glacier melt water, a glacial lake and lateral moraine are visual characteristics utilized in manual identification of the glacier perimeter. Finally, all the digital glacier outlines were placed into a geographic information system (GIS) to calculate the areal changes during the years 1966-2009.

\subsection{Accuracy analysis}

Analysis of the change in glacier area consistently indicates about $11.3 \%\left(29.2 \mathrm{~km}^{2}\right)$ area loss over the last $43 \mathrm{yr}$. However, there are some uncertainties in the glacier mapping. Generally, debris cover, snowfields and refreezing of water bodies are unavoidable factors affecting the accuracy of the mapping of glacier outlines and are difficult to evaluate. In the Gongga Mountains, the refreezing of water bodies could not occur during ablation periods and we do not discuss this
Table 2. Thresholds used for glacier mapping for all investigated Sensors.

\begin{tabular}{lll}
\hline Sensor & Snow and ice* & Snow and ice in shadow \\
\hline ASTER & AST3/AST4 $\geq 1.8$ & AST1 $>47$ \\
TM & TM3/TM5 $\geq 2.4$ & TM1 $>59$ \\
MSS & MSS3/MSS4 $\geq 2.0$ & MSS3 $>22$ \\
\hline
\end{tabular}

* Partly includes rocks in shadow.

unavoidable factor. In order to verify and improve the accuracy of glacier outlines, five glaciers (HLG, MZG, YZG, DGB and XGB Glaciers) were surveyed in April 2009 using dual frequency differential NavCom's GPS (SF-2040G, single-level positioning accuracy $\leq 10 \mathrm{~cm}$ ). The results show that there is about $\pm 30 \mathrm{~m}$ difference in the length and $0.5 \%$ in the area between our 100 surveyed points and the glacier mapping generated from ASTER data in 2009 (Fig. 2).

Another important uncertainty in the area change assessment is derived from the comparison of different data sources. Errors in glacier mapping can be caused by low image resolution and co-registration errors (Ye et al., 2006; Hall et al., 2003; Shangguan et al., 2009). Glacier area mapping from the comparatively low resolution $(80 \mathrm{~m})$ Landsat MSS image is less accurate than that from TM and ASTER images, especially for the smaller (area $<0.1 \mathrm{~km}^{2}$ ) and debriscovered glaciers. Similar problems have been reported by Hall et al. (2003) in Austria and Svoboda and Paul (2009) in Canada; however, Landsat MSS images remain an important resource since they are available for most parts of the world and provide some of the only data for the 1970s.

We calculated the errors of measured glacier outlines and co-registration as follows. The error in glacier area mapping, $\mathrm{E}$, was estimated as the root sum squares (RSS) of uncertainty error:

$E=\sqrt{\lambda^{2}+\varepsilon^{2}}$

where $\lambda$ is the uncertainty in the field survey and $\varepsilon$ is the registration error of image to the Landsat ETM+. In our case, according to the above equation, glacier terminus measurement uncertainty is $85.4 \mathrm{~m}, 42.4 \mathrm{~m}$ and $34.9 \mathrm{~m}$ for the periods 1966-1974, 1974-2005 and 2005-2009, respectively. Based on Hall et al. (2003) and Ye et al. (2006), the uncertainty in our estimation of glacier area is about $0.012 \mathrm{~km}^{2}$.

\section{Results}

\subsection{New glacier inventory data in 2009}

From 76 glaciers in the Gongga Mountains with a total area of $228.5 \mathrm{~km}^{2}$ (Fig. 1b; Table 3), $51.3 \%$ glaciers are smaller than $1 \mathrm{~km}^{2}$ and contribute to $7.1 \%$ to the total area, while $6.5 \%$ glaciers are larger than $10 \mathrm{~km}^{2}$ and contribute $45.7 \%$ of the total area (Fig. 3a). The distribution of the number 

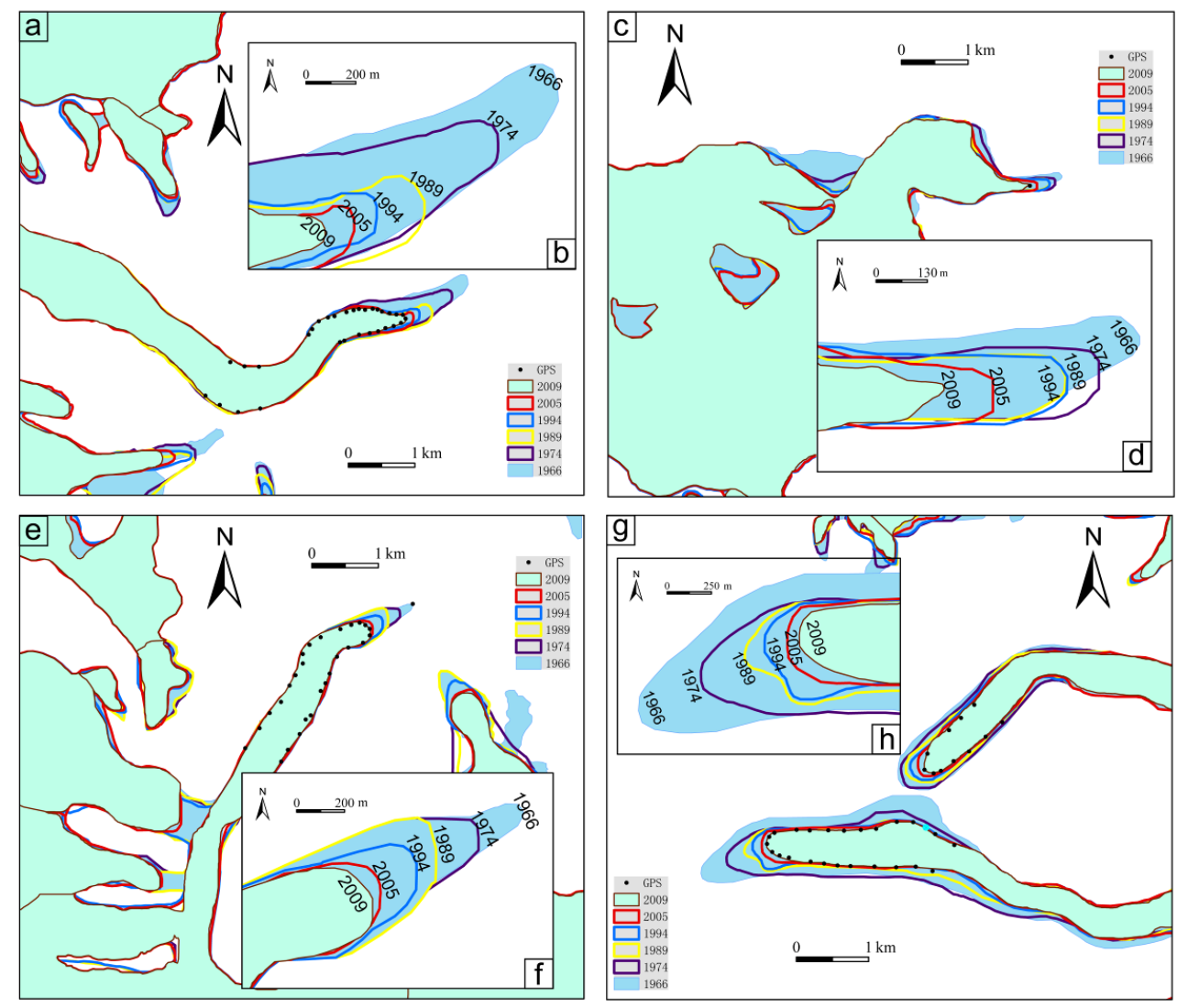

Fig. 2. Area changes and terminal retreat of the HLG (a and b), MZG (c and d), YZG (e and f) and DGB (g and h) Glaciers since 1966.

Table 3. Results of glacier mapping in 1966-2009.

\begin{tabular}{rrrrrr}
\hline Time & $\begin{array}{r}\text { Glacier } \\
\text { count }\end{array}$ & $\begin{array}{r}\text { Total area } \\
\left(\mathrm{km}^{2}\right)\end{array}$ & $\begin{array}{r}\text { Mean glacier area } \\
\left(\mathrm{km}^{2}\right)\end{array}$ & $\begin{array}{r}\text { Area change* } \\
\left(\mathrm{km}^{2}\right)\end{array}$ & $\begin{array}{r}\text { Rate of area change } \\
\left(\mathrm{km}^{2} \mathrm{yr}-1\right)\end{array}$ \\
\hline 1966 & 74 & 257.7 & 3.5 & - & - \\
1974 & 74 & 252.4 & 3.4 & -5.2 & -0.7 \\
1989 & 75 & 242.8 & 3.2 & -9.6 & -0.6 \\
1994 & 76 & 239.1 & 3.1 & -3.8 & -0.8 \\
2005 & 74 & 233.6 & 3.1 & -5.5 & -0.5 \\
2009 & 76 & 228.5 & 3.0 & -5.1 & -1.3 \\
\hline Total & & & -29.2 & -0.7 \\
\hline
\end{tabular}

* Area change is obtained by subtracting total area from two neighboring periods.

and area of glaciers by the median altitude (the elevation of contour line which divides the glacier area into two equal portions) is depicted in Fig. 3b. There are 25 glaciers with approximately $50 \%$ of the total glaciated area distributed between $5200 \mathrm{~m}$ and $5400 \mathrm{~m}$ (Fig. 3b). There is only one glacier reaching higher than $6000 \mathrm{~m}$ and one reaching lower than $4000 \mathrm{~m}$. On the eastern slope (Fig. 1b), there are 36 glaciers covering a total area of $139.9 \mathrm{~km}^{2}$, with a mean area of $3.9 \mathrm{~km}^{2}$. On the western slope, there are 40 glaciers covering an area of $87.6 \mathrm{~km}^{2}$, with a mean area of only $2.1 \mathrm{~km}^{2}$. The mean aspect of each glacier is calculated from the arc tangent of the respective sine and cosine grids following Paul (2007). The aspect of glaciers by number and area is shown in Fig. 3c; half the glaciers have south-western to south-eastern orientation, and make up $78 \%$ of the area (Fig. 3c). According to the calculation, there are no glaciers with northern or north-eastern orientation in the Gongga Mountains. In detail, the area of glaciers with a south-eastern orientation exceeded half of the total area (Fig. 3c), and the number of glaciers with a southern orientation account for about $20 \%$ 

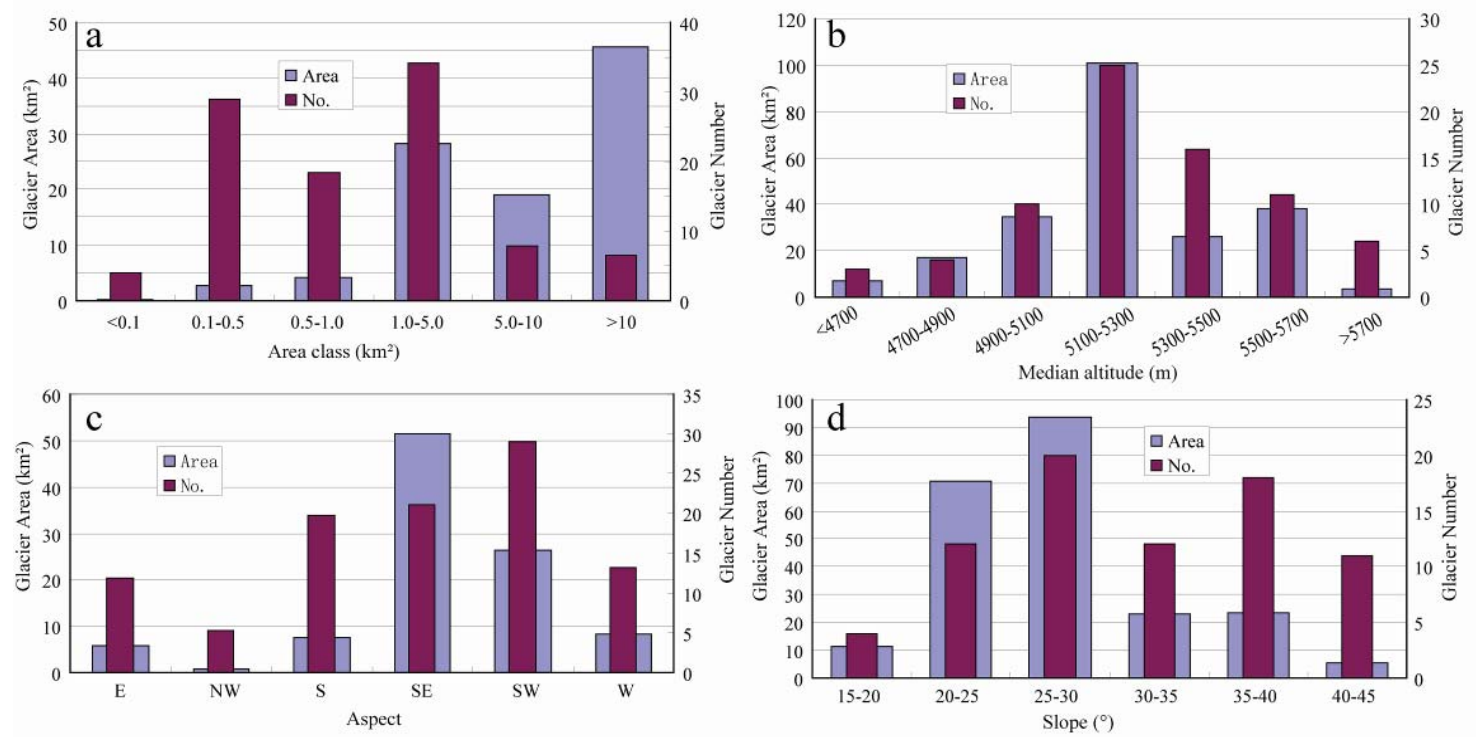

Fig. 3. Distribution of glaciers in 2009. (a) Distribution of glaciers in different area classes. (b) Distribution of glaciers by median altitude. (c) Distribution of glaciers by aspect. (d) Distribution of glaciers by mean slope.

of all glaciers, while their area represents $7.5 \%\left(16.9 \mathrm{~km}^{2}\right)$ of the total. The aspect distribution shows that the location of glaciers is dependent on local topographical constraints (Andreassen et al., 2008). The mean slope is a mean angle of glacier surface from the DEM. A dependence of glacier area and number on mean slope is observed, as depicted in Fig. 3d. It suggests that the slope of glaciers in the Gongga Mountains ranges from 15 to $45^{\circ}$ (Fig. 3d). Most glaciers (both in terms of area and number) have mean slopes of 20$30^{\circ}$ and few have slopes less than $20^{\circ}$ (Fig. 3d).

\subsection{Glacier changes}

The analysis of glacier area from 1966 (CGI) to 2009 (ASTER) reveals some interesting changes, as shown in Tables 3 and 4, and Fig. 2. The sample of 74 glaciers from the 1966 CGI covers a total area of $257.7 \mathrm{~km}^{2}$ (mean glacier area: $3.5 \mathrm{~km}^{2}$ ). The area of the largest glacier (YZG Glacier) is $30.1 \mathrm{~km}^{2}$, and the smallest is only $0.11 \mathrm{~km}^{2}$. From the 2009 ASTER inventory, the area of 76 glacier units is $228.5 \mathrm{~km}^{2}$ (mean glacier area: $3.0 \mathrm{~km}^{2}$ ), in which the maximum glacier is $25.5 \mathrm{~km}^{2}$ and the smallest glacier is only $0.05 \mathrm{~km}^{2}$. The total area loss of the glaciers is about $29.2 \mathrm{~km}^{2}(11.3 \%$ of the total area in 1966) with a rate of decrease of $0.7 \mathrm{~km}^{2} \mathrm{yr}^{-1}$ from 1966 to 2009 . The rate of area change $\left(-1.3 \mathrm{~km}^{2} \mathrm{yr}^{-1}\right)$ from 2005 to 2009 is the fastest in the whole period (Table 3), while the rate during 1994 to 2005 is the slowest, at $-0.5 \mathrm{~km}^{2} \mathrm{yr}^{-1}$ (Table 3). Due to glacier retreat, one glacier on the western slope separated into two smaller glaciers in 1974-1989 and two large glaciers (YZG Glacier) on the eastern slope were separated into two and three respectively from 1989-2009. Two small glaciers on the western slope with northern aspects disappeared between 1994 and 2005. In summary, the number of glaciers has increased by two and the area of glaciers has been reduced by $29.1 \mathrm{~km}^{2}$ during the period 1966-2009.

In the following we present glacier changes in detail by different classifications. On the eastern slope of the Gongga Mountains, the sample of 33 glaciers with an area of $155.1 \mathrm{~km}^{2}$ in 1966 has increased to 36 glaciers but with an area of $139.9 \mathrm{~km}^{2}$ in 2009 , representing a total area loss of $15.2 \mathrm{~km}^{2}(9.8 \%$ of the area in 1966). On the western slope, the sample of 41 glaciers with a total area of $102.6 \mathrm{~km}^{2}$ in 1966 has decreased to 40 glaciers with an area of $87.6 \mathrm{~km}^{2}$ in 2009 , and the area loss represents $14.6 \%$ of the total area in 1966. Glacier size strongly affects the percentage loss in glacier area. From 1966 to 2009, the area loss in the size classes $<0.5 \mathrm{~km}^{2}, 0.5-1 \mathrm{~km}^{2}, 1-5 \mathrm{~km}^{2}, 5-10 \mathrm{~km}^{2}$, and $>10 \mathrm{~km}^{2}$, equals $6.3 \%, 10.8 \%, 34.8 \%, 21.3 \%$ and $26.8 \%$, respectively (Table 4). The shrinkage of the glaciers in the size class of $1-5 \mathrm{~km}^{2}$ represents about $1 / 3$ of the total area loss (Fig. 4a and Table 4). The detailed data for each period can be found in Table 4. In comparing glaciers changes with altitude, the glaciers' area loss in the altitude range 5100$5300 \mathrm{~m}$ and $>5700 \mathrm{~m}$ is larger than that for other altitudes (Fig. 4b). The mean slope of all glaciers in this region ranges from $15^{\circ}$ to $45^{\circ}$, and glaciers with mean slopes of $15-20^{\circ}$ and $35-40^{\circ}$ (covering an area of $37.9 \%$ in 1966) exhibit the largest shrinkage (Fig. 4c). Glaciers with mean slopes of 25$30^{\circ}$ have the smallest area loss (Fig. 4c). The shrinkage of glaciers with northwest and east orientations is stronger than those with other aspects in this region, and glaciers with a southeast orientation experience the least shrinkage (Fig. 4d). 
Table 4. Comparison of glacier area for 74 glacier units from three different inventories: CGI (1966), Landsat MSS (1974), Landsat TM (1989, 1994 and 2005) and ASTER (2009). The area in 1966 is used as reference for area comparisons.

\begin{tabular}{|c|c|c|c|c|c|c|c|c|c|c|c|}
\hline \multirow{2}{*}{$\begin{array}{l}\text { Interval } \\
\text { area }\left(\mathrm{km}^{2}\right)\end{array}$} & \multicolumn{2}{|c|}{ Number in 1966} & \multirow{2}{*}{$\begin{array}{r}\text { Mean } \\
\text { Terminus (m) }\end{array}$} & \multirow{2}{*}{$\begin{array}{r}\text { Mean } \\
\text { Altitude (m) }\end{array}$} & \multicolumn{5}{|c|}{ Area change $\left(\mathrm{km}^{2}\right)$} & \multirow[b]{2}{*}{ Total $\left(\mathrm{km}^{2}\right)$} & \multirow[b]{2}{*}{ Area change $(\%)$} \\
\hline & $(n)$ & $(\%)$ & & & 09-05 & 05-94 & $94-89$ & $89-74$ & $74-66$ & & \\
\hline$<0.5$ & 22 & 29.7 & 5090.4 & 5416.4 & -0.4 & -0.4 & -0.6 & -0.1 & -0.3 & -1.8 & -6.3 \\
\hline $0.5-1.0$ & 16 & 21.7 & 4956.9 & 5455.9 & -0.4 & -0.7 & -0.3 & -1.3 & -0.4 & -3.3 & -10.8 \\
\hline $1.0-5.0$ & 24 & 32.4 & 4388.6 & 5332.9 & -1.7 & -1.8 & -1.4 & -3.6 & -1.6 & -10.1 & -34.8 \\
\hline $5.0-10.0$ & 6 & 8.1 & 4320.7 & 5116.7 & -1.6 & -0.8 & -1.0 & -1.7 & -1.1 & -6.2 & -21.3 \\
\hline$>10.0$ & 6 & 8.1 & 3616.6 & 5120.9 & -0.8 & -1.9 & -0.4 & -2.9 & -1.9 & -7.8 & -26.8 \\
\hline Total & 74 & 100.00 & & & -4.9 & -5.6 & -3.7 & -9.6 & -5.3 & -29.1 & -100 \\
\hline Area change $(\%)$ & & & & & -2.0 & -2.1 & -1.5 & -3.7 & -2.0 & -11.3 & - \\
\hline
\end{tabular}
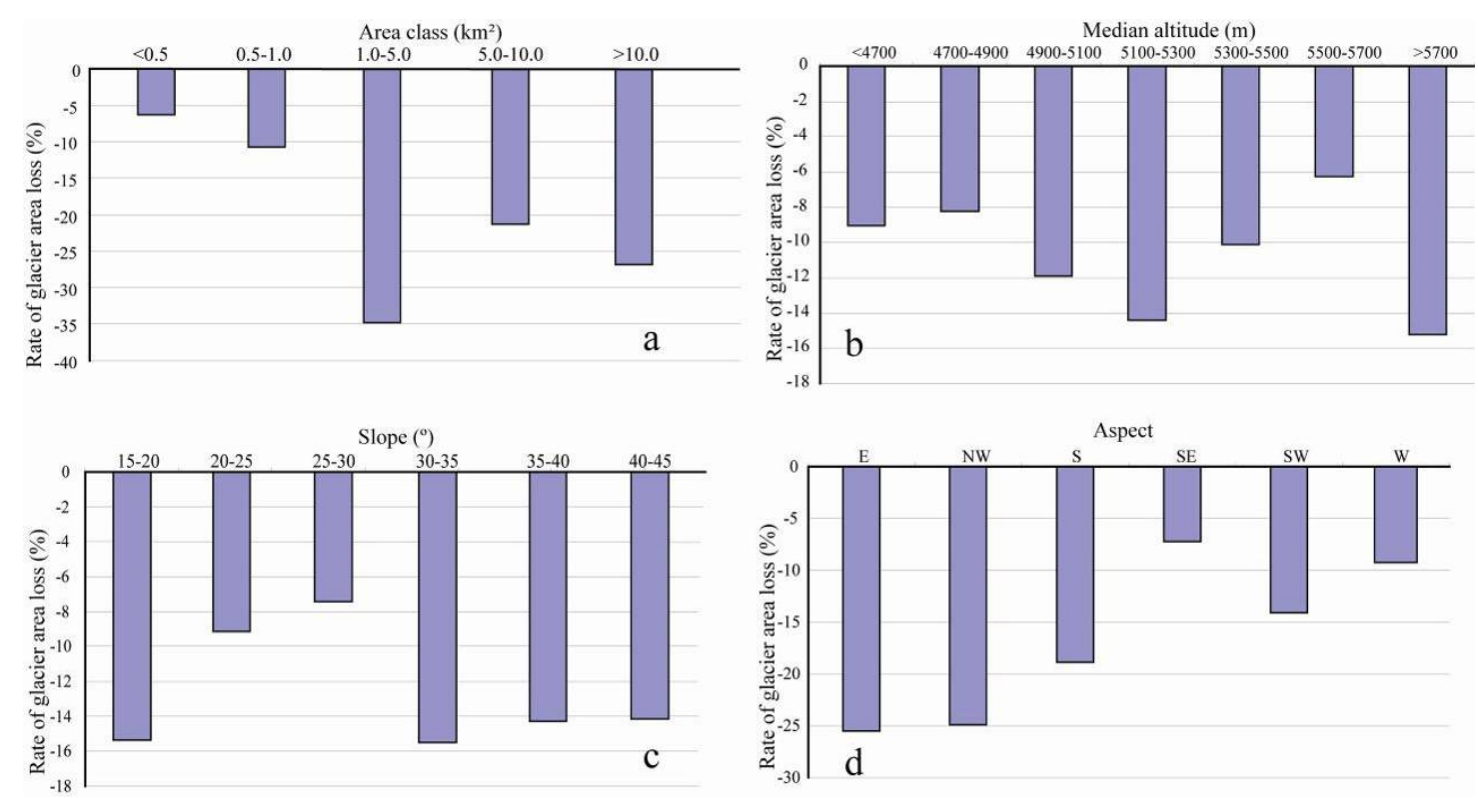

Fig. 4. The glacier changes between 1966 and 2009. (a) The relationship between area changes and area class. (b) The relationship between area changes and median altitude. (c) The relationship between area changes and mean slope. (d) The relationship between area changes and aspect.

\subsection{Exemples of glacier change}

Four glaciers with length of $10 \mathrm{~km}$ (the HLG, MZG, YZG and DGB Glaciers) are located in the investigation area and account for $39.4 \%\left(89.6 \mathrm{~km}^{2}\right)$ of the total glacier area in 2009. We studied their area change and front variations in detail.

\subsubsection{HLG Glacier}

In 1966, HLG Glacier was $12 \mathrm{~km}$ long and 250-1200 m wide, with an area of $25.7 \mathrm{~km}^{2}$. The glacier flows eastwards as it descends from $7556 \mathrm{~m}$ to $2980 \mathrm{~m}(\mathrm{Pu}, 1994)$. It has four distinct zones: the accumulation zone (from $7556 \mathrm{~m}$ to $4980 \mathrm{~m}$ ), a large icefall zone (from $4980 \mathrm{~m}$ to $3850 \mathrm{~m}$ ), a zone of glacier arches (from $3850 \mathrm{~m}$ to $3480 \mathrm{~m}$ ) and a debris covered zone (from $3480 \mathrm{~m}$ to $3980 \mathrm{~m}$ ) (Li et al., 2010a). According to Li (1996), the ELA of HLG is about $4900 \mathrm{~m}$ a.s.l. and about $0.28 \mathrm{~km}^{2}$ of glacial area is covered by thick debris. Many glaciologists have described the HLG Glacier in different ways (Heim, 1936; Cui, 1958; Su et al., 1992; Liu et al., 2010). For example, the length of the HLG Glacier was about $13 \mathrm{~km}$ in 1936 (Heim, 1936), decreased about $1 \mathrm{~km}$ from the 1930s to 1960s (Su et al., 1992), and was only $11 \mathrm{~km}$ in 2009 . Our investigation indicates that, from 1966 to 2009, the total retreat of the HLG Glacier was about $1146.4 \mathrm{~m}$ (about $26.7 \mathrm{~m} \mathrm{yr}^{-1}$ ), which can be separated into $29.3 \%, 34.3 \%, 16.5 \%, 9.0 \%$ and $10.9 \%$ for the periods of 1966-1974, 1974-1989, 1989-1994, 1994-2005, 20052009, respectively (Fig. 2a and b; Table 5). The highest retreat rate occurred during the period 1989-1994. Our results are in agreement with previous studies (Su et al., 1992; He et al., 2008; Liu et al., 2010; Li et al., 2010a). Moreover, its 
Table 5. Terminal retreat of four typical glaciers.

\begin{tabular}{lrrrrrrr}
\hline \multirow{2}{*}{$\begin{array}{l}\text { Glacier } \\
\text { name }\end{array}$} & \multicolumn{9}{c}{ Terminal retreat (\%) } & & $\begin{array}{r}\text { Total of terminal } \\
\text { retreat (m) }\end{array}$ & $\begin{array}{r}\text { Terminal retreat } \\
\left(\mathrm{m} \mathrm{yr}^{-1}\right)\end{array}$ \\
\cline { 2 - 6 } & $1966-1974$ & $1974-1989$ & $1989-1994$ & $1994-2005$ & $2005-2009$ & & \\
\hline HLG & -29.3 & -34.3 & -16.5 & -9.0 & -10.9 & -1146.4 & 26.7 \\
MZG & -24.1 & -17.7 & -21.7 & -12.3 & -24.2 & -501.8 & 11.7 \\
YZG & -28.3 & -25.1 & -13.5 & -23.8 & -9.3 & -724.8 & 16.9 \\
DGB & -40.7 & -27.6 & -11.8 & -13.1 & -6.8 & -1002.3 & 23.3 \\
\hline
\end{tabular}

area has shrunk by $3.1 \%$ (from $26.1 \mathrm{~km}^{2}$ in 1966 to $25.3 \mathrm{~km}^{2}$ in 2009) since 1966 (Table 6).

\subsubsection{MZG Glacier}

The area of MZG Glacier was $27.6 \mathrm{~km}^{2}$, with a length of $11.6 \mathrm{~km}$ in $1966(\mathrm{Pu}, 1994)$. The terminus elevation of MZG Glacier is $3600 \mathrm{~m}$ a.s.1., about $600 \mathrm{~m}$ higher than that of HLG Glacier. The ELA is about $5240 \mathrm{~m}$ a.s.1. and there is no debris cover on the glacier $(\mathrm{Pu}, 1994)$. The terminus of the MZG Glacier retreated about $501.8 \mathrm{~m}$ in length from 1966 to 2009 (Fig. 2c and d; Table 5). This relatively slow retraction may be attributed to its higher mean elevation and larger accumulation area ratio $(0.75)(\mathrm{Li}, 1996)$. The terminus of glacier is quite steep and narrow (Fig. 5b and c), and there is no debris cover on the ablation zone of the glacier. The glacier change in MZG is different from other glaciers. This is an important question and we will explore it in future work. From 1966 to 2009, the shrinkage area of MZG Glacier is $7.7 \%$ (Table 6), which is larger than that of the HLG and YZG Glaciers. By comparing remote sensing images from 1974, 1989, 1994, 2005 to 2009 with CGI, we found that some parts of the MZG Glacier lay beneath a blanket of snow in the images except 2009; hence the snowfields were included in the determination of the glacier outline. When the snowfields melted away in 2009 (Fig. 5a), the glacier area exhibited a sudden shrinkage. In Fig. 5a (Uncertain area), although some glacier change was found, we could not identify whether the MZG Glacier has been already separated into two parts because of difficulty in verifying by a steep cliff along glacier terminus (Fig. 5b and c).

\subsubsection{YZG Glacier}

The YZG Glacier was $30.1 \mathrm{~km}^{2}$ in area and $10.5 \mathrm{~km}$ in length, with the terminus elevation of $3680 \mathrm{ma}$ a.s. ( $\mathrm{Pu}$, 1994). The ELA is about $4840 \mathrm{~m}$ a.s.l. for YZG Glacier and about $0.81 \mathrm{~km}^{2}$ in the ablation area was covered by debris $(\mathrm{Pu}, 1994)$. The terminus of the YZG Glacier retreated $724.8 \mathrm{~m}$ (about $16.9 \mathrm{~m} \mathrm{yr}^{-1}$ ) during the period 1966-2009 (Fig. 2e and f; Table 5). The terminus retreat rate $\left(25 \mathrm{~m} \mathrm{yr}^{-1}\right)$ was at its maximum between 1966 and 1974. The area of the glacier decreased from $30.1 \mathrm{~km}^{2}$ in 1966 to $20.2 \mathrm{~km}^{2}$ in 2009. Furthermore, the YZG Glacier separated into three parts between 1966 and 2009, in which two glaciers were separated from the YZG Glacier during the period 19891994 and 1994-2009 (Table 3). The fieldwork in 2009 also illustrates this evidence. These three glaciers cover areas of $20.2 \mathrm{~km}^{2}, 2.9 \mathrm{~km}^{2}$ and $6.0 \mathrm{~km}^{2}$, respectively.

\subsubsection{DGB and XGB Glaciers}

The DGB and XGB Glaciers formed a single glacier before the 17 th century. However, they separated into two independent glaciers during the early 17th to middle 19th century (Li, 1996). According to the description of Heim (1936), the DGB Glacier was about $10 \mathrm{~km}$ long, and the terminus ended at a height of $3800 \mathrm{~m}$ a.s.l. Su et al. (1992) have also described the situation of the glacier. They stated that the overlap of the recent and older moraines formed a great cone, which was about $240 \mathrm{~m}$ above the valley floor, and there was no distinct boundary between the present terminus and the fresh moraines around the DGB Glacier. According to our results, the terminus of the DGB Glacier has retreated about $1002.3 \mathrm{~m}$ (Fig. $2 \mathrm{~g}$ and h; Table 5) from 1966 to 2009, and in 2009 was located at an elevation of about $4000 \mathrm{~m}$ a.s.l., which is approximately $200 \mathrm{~m}$ higher than that in 1936 . The length of the glacier was reduced by about $685.7 \mathrm{~m}$ in the period 1966-1989 and $316.5 \mathrm{~m}$ in the period 1989-2009. The total area of DGB Glacier has reduced by $2.4 \mathrm{~km}^{2}(11.2 \%)$, from $21.5 \mathrm{~km}^{2}$ in 1966 to $19.1 \mathrm{~km}^{2}$ in 2009 (Table 6); the area shrinkage during the period 1966-1989 accounts for $78 \%$ of the total area loss. Although the shrinkage rate on the western slope was generally higher than that on the eastern side, the terminus of DGB Glacier remained relatively stable during the last decade because the ablation zone was covered by a thick of 0.06-1.6 m debris layer ( $\mathrm{Li}, 1996)$. The field investigation in 2009 showed that the surface elevation of DGB Glacier is about forty meters lower than its fresh lateral moraines. The XGB Glacier is smaller than the DGB Glacier, and is also debris-covered. The terminus of the XGB Glacier retreated about $378 \mathrm{~m}$ in the last $43 \mathrm{yr}$, and the total area diminished by $14.6 \%$ (from $6.7 \mathrm{~km}^{2}$ in 1966 to $5.7 \mathrm{~km}^{2}$ in 2009).

In summary, the terminus of four glaciers have similar retreating behavior (Table 5). We also found that the retreating 
Table 6. Area changes of four typical glaciers.

\begin{tabular}{|c|c|c|c|c|c|c|c|}
\hline \multirow[t]{2}{*}{$\begin{array}{l}\text { Glacier } \\
\text { name }\end{array}$} & \multicolumn{5}{|c|}{$\begin{array}{l}\text { Area change of } \\
\text { Glacier }\left(\mathrm{km}^{2}\right)\end{array}$} & \multirow[t]{2}{*}{$\begin{array}{l}\text { Total of area } \\
\text { changes }\left(\mathrm{km}^{2}\right)\end{array}$} & \multirow[t]{2}{*}{$\begin{array}{l}\text { Area change } \\
(\%)\end{array}$} \\
\hline & 1966-1974 & 1974-1989 & 1989-1994 & 1994-2005 & 2005-2009 & & \\
\hline HLG & -0.1 & -0.2 & -0.2 & -0.2 & -0.1 & -0.8 & -3.1 \\
\hline MZG & -0.3 & -1.1 & -0.1 & -0.2 & -0.4 & -2.1 & -7.7 \\
\hline YZG* $^{*}$ & -0.4 & -0.1 & -0.2 & -0.3 & -0.1 & -1.1 & -3.7 \\
\hline DGB & -1.0 & -0.9 & -0.1 & -0.1 & -0.3 & -2.4 & -11.2 \\
\hline
\end{tabular}

* Including two small glaciers.
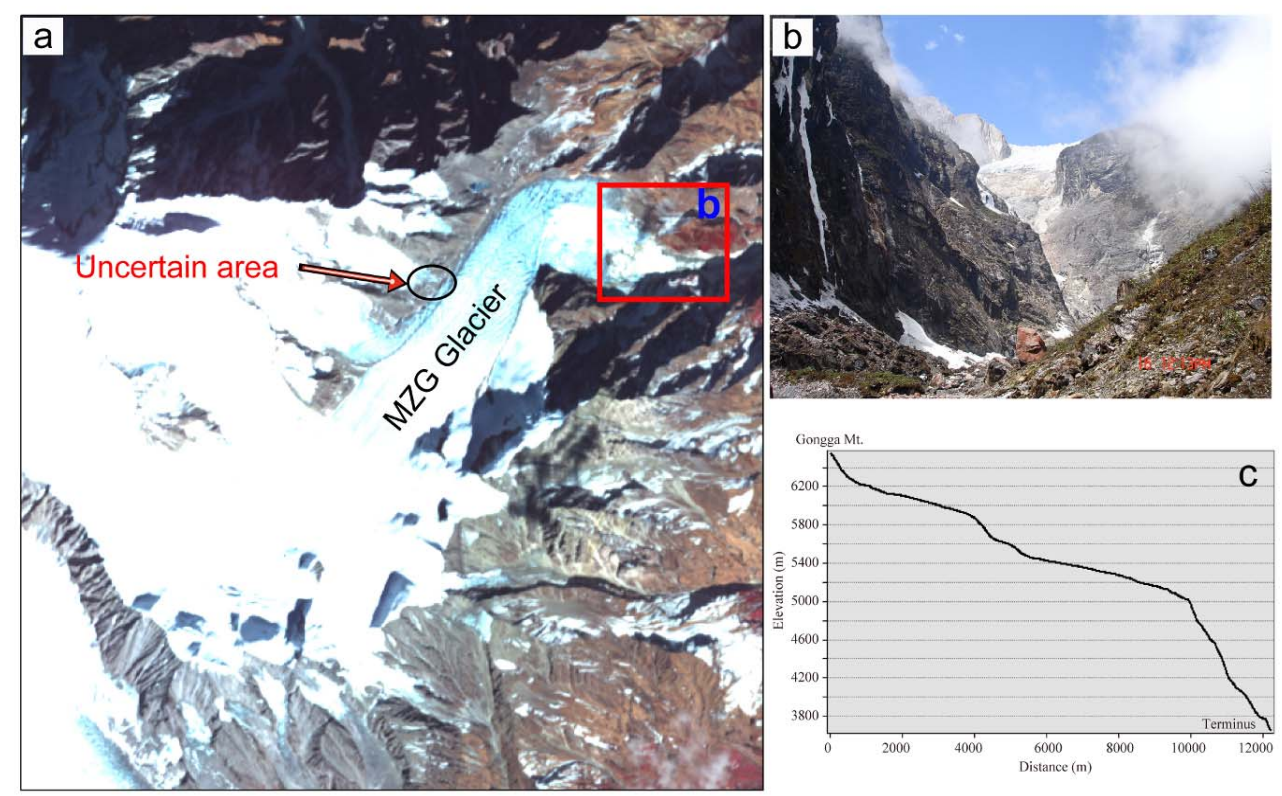

Fig. 5. (a) ASTER image showing the MZG Glacier in 2009. (b) Field photo showing the terminus of the MZG Glacier in 2009. (c) The longitudinal profile of the MZG Glacier from the 1989 DEM.

of terminus in periods 1966-1974 was faster than that in others periods.

\subsection{Comparison of glacier changes in Gongga Mountains with other regions}

A portion glacier changes in China were compared in this study (Table 7). In the Gangrigabu Mountains, Liu et al. (2006) conclude that the glaciers, which are also monsoonal temperate glaciers, have retreated $13.8 \%$ (about $2.1 \%$ per decade) in area and $9.8 \%$ (about $1.5 \%$ per decade) in volume, respectively, from 1915 to 1980 . The glaciers in the west Kunlun Shan (WKS), which are extreme continental type glaciers, have decreased by about $0.4 \%$ in area during the period 1970-2001 (Shangguan et al., 2007). According to Shangguan et al. (2006), the glacier (sub-continental type glacier) area has decreased by $4.1 \%$ (about $1.4 \mathrm{~km}^{2}$ per decade) in the Karakoram Mountains between 1969 and 1999. Li et al. (2008) summarized the current status of the cryosphere in China and its changes based on the latest available data. The investigation indicated that glacier areas in China have shrunk about $2-10 \%$ over the past $45 \mathrm{yr}$ and that the total area has receded by about $5.5 \%$ (Li et al., 2008). Moreover, Kang et al. (2004) suggested that the area change of monsoonal temperate, sub-continental and extreme continental type glacier is $-8.9 \%,-6.0 \%$ and $-2.4 \%$, respectively, from the 1960 s to 2000 . Those results indicate that the change of monsoonal temperate type glacier is remarkable. Comparing with above research, the rate of glacier retreat in the Gongga Mountains (11.3\% reduction in glacier area from 1966 to 2009 , and about $2.6 \%$ per decade) is similar to that for glaciers of the same type but faster than that of continental type glaciers in the west of China. 
Table 7. The glacier changes of three types in China

\begin{tabular}{|c|c|c|c|c|c|}
\hline $\begin{array}{l}\text { Study } \\
\text { Area }\end{array}$ & $\begin{array}{l}\text { Glacier } \\
\text { type }\end{array}$ & Periods & $\begin{array}{r}\text { Glacier } \\
\text { Changes } \\
(\%)\end{array}$ & $\begin{array}{r}\text { Rate of } \\
\text { glacier changes } \\
\left(\% \mathrm{a}^{-1}\right)\end{array}$ & $\begin{array}{r}\text { Document } \\
\text { Source }\end{array}$ \\
\hline The Western Kunlun Shan & Extreme continental & 1970-2001 & -0.4 & 0.01 & Shangguan et al. (2007) \\
\hline The Western Nyainqêntanglha Range & Extreme continental & 1970-2000 & -5.7 & 0.19 & Shangguan et al. (2008) \\
\hline Geladandong Mountain & Sub-continental & 1969-2002 & -4.7 & 0.16 & Ye et al. (2006) \\
\hline Karakoram Mountains & Sub-continental & 1969-1999 & -4.1 & 0.14 & Shanguan et al. (2006) \\
\hline Gangrigabu Range & Monsoonal temperate & $1915-1980$ & -13.8 & 0.18 & Liu et al. (2005) \\
\hline Gongga Mountain & Monsoonal temperate & 1966-2009 & -11.3 & 0.26 & This study \\
\hline
\end{tabular}

\section{Discussion}

\subsection{Climate changes}

In this study we use temperature and precipitation data from three meteorological stations (Fig. 1b), which are located close to the glaciers in the Gongga Mountains. They are Hailuogou meteorological station (3000 ma.s.1.) on the eastern slope (Fig. 1b), and Jiulong meteorological station (2993 m a.s.1.) and Xinduqiao meteorological station (3640 ma.s.1.) on the western slope (Fig. 1b). Climate records from these stations (Fig. 6) were analyzed to evaluate the impact of temperature and precipitation on glacier retreat. The meteorological data was processed by Microsoft Excel 2003, and the trend line was calculated by one-dimensional liner regression. The mean annual temperature of all three stations has increased over the last forty decades, and the warming rate of the HLG meteorological station $\left(0.34 \mathrm{~K} \mathrm{decade}^{-1}, 1988-2009\right)$ is faster than that of the Jiulong meteorological station $\left(0.24 \mathrm{~K} \mathrm{decade}^{-1}\right.$, $1988-$ 2009) (Fig. 6). During 1966-2009, the warming rates of Jiulong and Xinduqiao meteorological data are both about $0.14 \mathrm{~K} \mathrm{decade}^{-1}$ (Fig. 6). In the south-eastern margin of the Qinghai-Tibetan Plateau, evidence of long-term climate change derived from tree-rings (He et al., 2003) and an ice core (Thompson et al., 2000) also indicate a rapid warming trend in the past millennia. The mean annual precipitation has only increased by $1 \%$ (Fig. 6) in the last 50 yr. Mass-balance modeling (Oerlemans, 2001; Braithwaite and Zhang, 2000), indicates that a $25 \%$ increase in annual precipitation is typically needed to compensate for the mass loss due to a uniform $1 \mathrm{~K}$ warming. Precipitation, radiation and air temperature are the most important factors in determining the glacier mass balance. Oerlemans and Fortuin (1992) proposed that mass balance sensitivity was only affected by annual precipitation and that glaciers in a wetter regime are more sensitive. According to their modeling, the change of mean specific balance for a $1 \mathrm{~K}$ warming, uniform through the year, varied from -0.12 to $-1.15 \mathrm{~m} \mathrm{yr}^{-1}$ (Oerlemans and Fortuin, 1992). Fujita (2008) suggested that the effects of latitude and annual precipitation amount on the mass balance sensitivity are less than those of precipitation seasonality and its concentration. Fujita's calculations suggest higher sensitivities for the glaciers located in a summer-precipitation climate than for those located within a winter-precipitation climate (Fujita, 2008). In the Gongga Mountains, the mean annual temperature has increased by $0.5 \mathrm{~K}$ since the $1960 \mathrm{~s}$, while the mean annual precipitation has increased by $1 \%$. In addition, the Gongga Mountains have a wetter regime and belong to a summer-precipitation climate. The mass balance of glaciers in Gongga Mountains is more sensitive to the temperature changes. As a consequence, the increasing amount of precipitation $(1 \%)$ cannot compensate for the mass loss due to temperature increase $(0.5 \mathrm{~K})$. Therefore, the glacier area shrinkage of $11.3 \%$ in the Gongga Mountains could be attributed to the temperature increase. Climate warming, however, did not always result in glacial recession owing to increased precipitation. This phenomenon also occurred for TIRB (Tarim Interior River Basin), where glacier area decreased by $3.3 \%$ from the $1960 \mathrm{~s} / 1970$ s to $1999 / 2001$ under the warming of $0.77 \pm 0.16 \mathrm{~K} / 40 \mathrm{a}$ and precipitation increase of $22.8 \pm 7.9 \%$ (Shangguan et al., 2009).

\subsection{Glacier response to climate changes}

The rate of glacier retreat in the Gongga Mountains was $0.6 \mathrm{~km}^{2} \mathrm{yr}^{-1}$ from 1966 to 1974 (Table 3 and Fig. 7), slowed slightly during the period 1974-1989, and then became rapid in the period 1989-1994. It was the slowest $\left(0.5 \mathrm{~km}^{2} \mathrm{yr}^{-1}\right)$ from 1994 to 2005, and after 2005, reached its most rapid rate of $1.3 \mathrm{~km}^{2} \mathrm{yr}^{-1}$. In order to explore causes of glacier retreat in different time intervals, the meteorological data from Jiulong station, which has the longest and most reliable data (1953-2009), were averaged with the same time interval as glacier reduction (Fig. 7). From the meteorological data (Fig. 6), we find that the annual precipitation increased gradually while the annual temperature increased rapidly in the period 1960-2009. Comparing glacier area with annual temperature for each period, we find a negative relationship (Fig. 7), with glacier area decreasing while annual temperature increases. The mean temperature gradually increased in the period 1966-1994 and then rapidly increased after 1994 (Fig. 8); the mean precipitation shows a remarkable fluctuation in the period 1966-2009. The mean precipitation was 

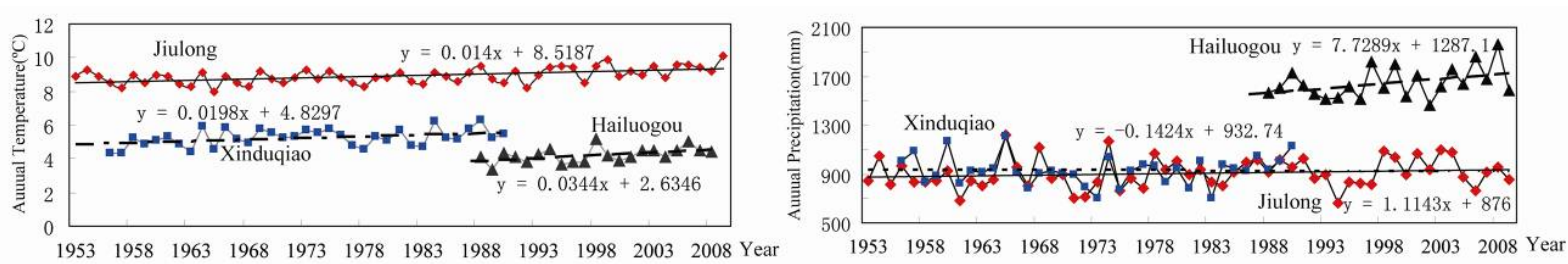

Fig. 6. Meteorological (mean annual temperature and annual precipitation) data for Gongga Mountain from 1960 to 2009.

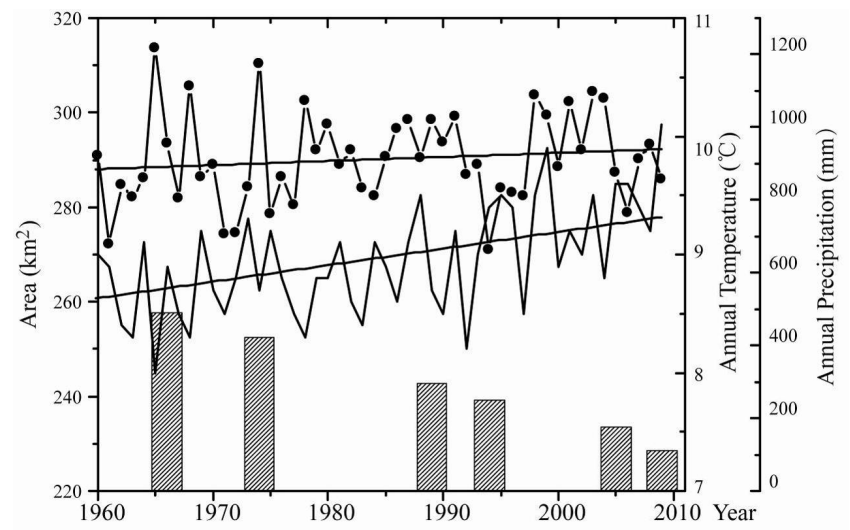

Fig. 7. Glacier areas and meteorological data from Jiulong Station from 1960 to 2009. The bars show total area in 1966, 1974, 1989, 2005 and 2009. The dots show annual precipitation and the polyline shows mean annual temperature.

highest from 1994 to 2005 and smallest from 2005 to 2009. The mean retreat rate of glaciers also fluctuated over the period 1966-2009. Comparing the mean temperature with mean retreat rate of glaciers, the retreat rate is not related in a clear way to the mean temperature, while the mean precipitation shows a close correspondence with retreat rate (Fig. 8). When the mean precipitation is high, the retreat rate is slow, and vice versa (Fig. 8). The retreat rate of glaciers in the Gongga Mountains is similar to that found by Yao et al. (2004) in the southeast Tibetan Plateau and Karakorum Mountains. The increase in precipitation probably weakens the rate of glacier retreat; in contrast, the decrease in precipitation aggravates the rate of glacier reduction. Therefore, the trend of glacier retreat is driven by the warming climate, but the rate of retreat is mainly affected by precipitation.

In general, the quantitative relationship between the glacier termini fluctuations and climate change is complicated by a time lag between climate change and glacier response (Jóhannesson, 1989). According to Porter (1986), small temperate glaciers in low- and mid-latitudes are especially sensitive to climate change, and the dynamic response of the terminus is generally rapid with a lag time of a decade or less. Wang and Zhang (1992) considered that there was a phase lag of 12-13 yr for glacier response to climatic change in the Northern Hemisphere on the basis of their analysis of

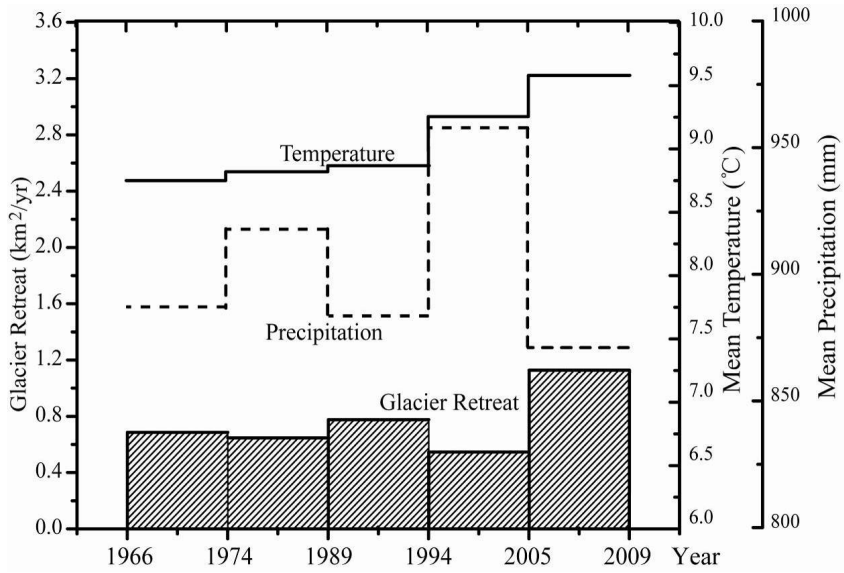

Fig. 8. The relationship between glacier retreat and climate change. Bars show glacier retreat, the black dashed line is mean precipitation and the black solid line is mean temperature.

numerous glacier advance and positive mass-balance cases. The time lag is affected by several conditions, such as glacier size, glacier bed slope, and glacier type. Based on the study of Pelto and Hedlund (2001), HLG, YZG, MZG and DGB Glaciers are all type 1 glaciers, which are distinguished by steeper slopes, extensive crevassing and higher terminus region velocities. The lag time of this type glacier should be 4 to $16 \mathrm{yr}$.

Monsoonal temperate glaciers in China mainly cover the southeastern part of Qinghai-Tibetan Plateau. The area of monsoonal temperate glaciers is about $13203 \mathrm{~km}^{2}$, accounting for $22.2 \%$ of the total glacier area in China (Su and Shi, 2002). According to Thompson et al. (2000), Dasuopu cores suggest a large-scale, plateau-wide 20th-century warming trend that appears to be amplified at higher elevations. Two records in the southeastern Tibetan Plateau of temperate glaciers indicate that temperatures in the 17th century were $0.8 \mathrm{~K}$ colder than the present (Shi and Liu, 2000). However, the estimate of Jones et al. (1999) shows a worldwide temperature decrease in the same period of $0.5-0.8 \mathrm{~K}$, which is just half that occurring in western China. In this region, air temperature has risen to $0.8 \mathrm{~K}$ on average since the Maxima of the Little Ice Age and the glacier area has decreased by $3700 \mathrm{~km}^{2}$, which corresponds to $29 \%$ of the area of existing glaciers (Shi and Liu, 2000). Glaciers in the Gongga 
Table 8. A comparison of HLG and YZG glacier features (Pu, 1994).

\begin{tabular}{lrrrrrrr}
\hline $\begin{array}{l}\text { Glacier } \\
\text { Name }\end{array}$ & $\begin{array}{r}\text { Area } \\
\left(\mathrm{km}^{2}\right)\end{array}$ & $\begin{array}{r}\text { Length } \\
(\mathrm{km})\end{array}$ & $\begin{array}{r}\text { Terminus Altitude } \\
(\mathrm{m})\end{array}$ & $\begin{array}{r}\text { Top Altitude } \\
(\mathrm{m})\end{array}$ & $\begin{array}{r}\text { Median Altitude } \\
(\mathrm{m})\end{array}$ & $\begin{array}{r}\text { Slope } \\
\left({ }^{\circ}\right)\end{array}$ & $\begin{array}{r}\text { Aspect } \\
\text { HLG }\end{array} 25.7$ \\
\hline YZG & 30.1 & 10.5 & 2980 & 7556 & 5427 & 26.9 & southeast \\
northeast
\end{tabular}

Mountains are important monsoonal temperate glaciers. The glacier areas losses $(11.3 \%)$ of Gongga Mountains agree well with the results by Shi and Liu (2000), and also prove the climate warming in this region.

\subsection{Glacier changes with topographic factors}

The Gongga Mountains run approximately north-south, and the number of glaciers was respectively 36 and 40 on the eastern and western slope in 2009. The rate of area loss on the western slope $(14.6 \%)$ is slightly faster than that on the eastern slope $(9.8 \%)$ of the Gongga Mountains. According to meteorological data, the mean annual temperature rise is faster on the eastern than the western slope and the precipitation on both slopes increases in similar magnitude $(\sim 1 \%)$. The difference in glacier area loss on each slope cannot be well explained by climate records individually, and thus we calculate the topographical characteristic (slope, aspect, altitude and glacier size) of both slopes to track their influences on glacier changes. The mean slope is $32^{\circ}$ on the eastern slope and $29^{\circ}$ on the western slope; the aspect is mainly south or southeast on the eastern slope and south or southwest on the western slope; and the mean median altitude is $5400 \mathrm{~m}$ on the eastern slope and $5300 \mathrm{~m}$ on the western slope. Bøcker (1996) suggested that aspects and slopes are important factors affecting glacier changes. In their study of glacier regime on the northern slope of the Himalaya, Aizen et al. (2002) argued that the melting of the glaciers is driven by solar radiation (up to $86 \%$ ), based on the meteorological station records. There is no significant difference in topographic factors between eastern and western slopes, and thus we extrapolate that the incoming solar radiation affected by the aspects and slopes cannot cause the difference of glaciers changes (Bøcker, 1996) between eastern and western slopes in the Gongga Mountains. We find that the mean glacier size on the western slope $\left(2.2 \mathrm{~km}^{2}\right)$ is smaller than that on the eastern slope $\left(3.9 \mathrm{~km}^{2}\right)$. Hence, we may speculate that different retreat rates on each slope are probably caused by the difference in glacier size. This result agrees well with Haeberli and Beniston's (1998) finding that small glaciers are more sensitive to climate changes. Although climate warming has been the main cause for glacier changes during the last $43 \mathrm{yr}$, the topographic factor also plays an important role. For example, the HLG and the YZG Glaciers are located on the eastern slope, but the terminus of HLG Glacier (2980 $\mathrm{m}$ a.s.1.) is lower than YZG Glacier (3680 ma.s.1.) (Pu, 1994). The temperature of terminus of YZG Glacier is about $2.8 \mathrm{~K}$ lower than that of HLG Glacier based on the temperature gradient $(0.43 \mathrm{~K} / 100 \mathrm{~m})$ in HLG Valley (Su et al., 1996). Additionally, the aspects of HLG and YZG Glaciers are southeast and northeast, respectively, which cause more radiation income on HLG Glacier than on YZG Glacier. These different factors will cause more intense ablation for HLG Glacier than YZG Glacier (Table 8).

The debris thickness could also affect the ablation of glaciers (Li, 1996; Nicholson and Benn, 2006). Zhang et al. (2011) note that about $67 \%$ of the ablation area on HLG Glacier has undergone accelerated melting, whereas about $19 \%$ of the ablation area has experienced inhibited melting, and the sub-debris melt rate equals the bare-ice melt rate in only $14 \%$ of the ablation area because of the inhomogeneous distribution of debris thickness. The glacier ablation in the Gongga Mountains becomes weaker with increased debris thickness and no ablation occurs when the thickness of the debris is $2 \mathrm{~m}$ ( $\mathrm{Li}, 1996)$. At present, we have limited data on debris thickness, and cannot evaluate the ablation of the debris-covered glacier. However, the thick debris may play a crucial role in suppressing ablation in the terminus (Zhang et al., 2011), but the ice crevasses and subglacial river may also cause accelerated ablation. In summary, at a large spatial scale, the glaciers' change has been mainly controlled by climate change, while on a small scale, the glaciers' change has also been affected by topographic factors.

When the glaciers are grouped according to size classes (according to their CGI area) (Table 4 and Fig. 4a), this shows that glaciers with areas of $1-5 \mathrm{~km}^{2}$ have a more notable reduction in area than other sizes of glacier. The relationship between glacier change and size differs from other regions; for example, in TIRB, Shangguan et al. (2009) show that glacier losses are most serious for glaciers with areas of $0.2-0.5 \mathrm{~km}^{2}$. Of the glaciers with area $1-5 \mathrm{~km}^{2}, 75 \%$ have mean slopes below $30^{\circ}$ and most are oriented southeast to southwest. Additionally, the largest number of glaciers fall into this size class (Fig. 4a). Although two small glaciers have vanished, the rate of retreat for glaciers with areas less than $0.5 \mathrm{~km}^{2}$ is slowest (Fig. 4a). This phenomenon is also found in the Monashee Mountains of Canada, where very small glaciers $\left(\right.$ area $<0.4 \mathrm{~km}^{2}$ ) showed no observable net change in area (DeBeer and Sharp, 2009). DeBeer and Sharp (2009) suggest that these very small glaciers are sheltered from direct solar radiation or are located at relatively high elevations and typically reside in sites that receive 
enhanced mass inputs either from avalanching from upper contributing slopes or wind drift onto leeward slopes. These explanations also suit glacier change in the Gongga Mountains. Thus, we can infer that small glaciers are more sensitive to climate changes but that these glaciers with areas less than $0.5 \mathrm{~km}^{2}$ are poorly coupled to the regional climate because of their local topographic setting.

The rate of glacier loss is largest for glaciers with median altitude $>5700 \mathrm{~m}$ and second largest for those with median altitudes of 5100-5300 m. Glacier loss becomes smaller with increased mean slope up to $30^{\circ}$, beyond which it becomes relatively constant (Fig. 4c). Glaciers with east, northwest and south orientation have an obvious shrinkage (Fig. 5d). Although we cannot find strong correlations between glacier retreat rates and topographic factors, we expect that glacier size, slope and aspect probably influence the rate of glacier retreat in the Gongga Mountains.

\section{Conclusions}

In this study, we present results from the new glacier inventory of the Gongga Mountains, covering 76 glaciers and $228.5 \mathrm{~km}^{2}$ in 2009 , and from serial glacier mapping since the 1960s in the same area, including a statistical analysis of the inventory data and a calculation of area and length changes from 1966 to 2009. The glacier area of 74 glaciers in the Gongga Mountains shrank by $11.3 \%\left(\sim 29.2 \mathrm{~km}^{2}\right)$ or $\sim 2.6 \%$ per decade since 1966 . The glacier retreat rate (by area) over the period 1966-2009 is higher than most other regions in China. Moreover, the area loss is more notable on the western slope $(-14.6 \%$ since 1966) than the eastern slope $(-9.8 \%$ since 1966). The rate of glacier reduction is notable between 1966 and 1994, became slower during the period 1994-2005, and reached its fastest rate during the period 2005-2009. This trend in glacier retreat rates over time is similar to that for other glaciers in the southeast of the Qinghai-Tibetan Plateau. The retreat is mainly caused by the increase in temperature, while also affected by the amount of precipitation. Rate of glacier area retreat is not only controlled by climate change but also topographic setting, glacier size, and type. The more rapid glacier retreat on the western slope than on the eastern slope can be explained by the difference in glacier size. Although the terminus and area of the largest glaciers show a striking retraction, the smaller glaciers also make important contributions to area changes, especially in response to climate changes since they are more sensitive to climate change in local regions and over short timescales. The smallest glaciers with areas less than $0.5 \mathrm{~km}^{2}$ are poorly coupled to the regional climate since they are strongly controlled by their local topographic setting. Glacier retreat rates in the Gongga Mountains are similar to other areas with the same glacier type but faster than the continental type glaciers in the west of China.
Acknowledgements. We thank K. Fujita, M. Pelto and an anonymous referee for helpful comments and suggestions. We thank the US geological survey which provided the website (http://glovis.usgs.gov/ImgViewer/Java2ImgViewer.html). We also thank the Gongga Alpine Ecosystem Observation and Research Station of Chinese Ecological Research Network and China Meteorological Data Sharing Service System (http://cdc.cma.gov.cn/), for providing temperature and precipitation data. This work was funded by the National Basic Work Program of the Ministry of Science and Technology of China (Glacier Inventory of China II, grant No. 2006FY110200), the National Science Fund for Distinguished Young Scholars (No. 40925001), NSFC Innovation Team Project (No. 40421101) and the foundation of State Key Laboratory of Cryospheric Sciences, Cold and Arid Regions Environment and Engineering Research Institute, Chinese Academy Sciences (No. SKLCS 2011-03). We acknowledge Emily Derbyshire, Hu Xiaofei and David Milledge who provided language help.

Edited by: G. H. Gudmundsson

\section{References}

Ageta, Y. and Higuchi, K.: Estimation of mass balance components of a summer-accumulation type glacier in the Nepal Himalaya, Geogr. Ann. A, 66, 249-255, 1984.

Aizen, V. B., Nikitin, S. A., and Song, G.: Model of the dynamics of the Hailuogou glacier (southeastern Xizang), in: Glaciers and environment in the Qinghai-Xizang (Tibet) Plateau (I) - the Gongga Mountain: reports on the Sino-Russian Joint Glaciological Expedition, edited by: Xie, Z. and Kotlyakov, V. M., Beijing and New York, Science Press, 121-132, 1994.

Aizen, V. B., Aizen, E. M., and Nikitin, S. A.: Glacier regime on the northern slope of the Himalaya (Xixibangma glaciers), Quaternary Int., 97-98, 27-39, 2002.

Aizen, V. B., Kuzmochenok, V. A., Surazakov, A. B., and Aizen, E. M.: Glacier changes in the Central and Northern Tien Shan during the last 140 years based on surface and remote-sensing data, Ann. Glaciol., 43, 202-213, 2006.

Albert, T. H.: Evaluation of remote sensing techniques for ice-area classification applied to the tropical Quelccaya ice cap, Peru. Polar Geogr., 26, 210-226, 2002.

Anderson, J. G.: Topographical and archaeological studies in the Far East, Östasiatiska Samlingarna Bulletin (Stockholm), 11, 1-111, 1939.

Andreassen, L. M., Paul, F., Kääb, A., and Hausberg, J. E.: Landsatderived glacier inventory for Jotunheimen, Norway, and deduced glacier changes since the 1930s, The Cryosphere, 2, 131-145, doi:10.5194/tc-2-131-2008, 2008.

Arendt, A. A., Echelmeyer, K. A., Harrison, W. D., Lingle, C. S., and Valentine, B.: Rapid wastage of Alaska glaciers and their contribution to rising sea level, Science, 297, 382-386, 2002.

Barry, R. G.: The status of research on glaciers and global glacier recession: a review, Prog. Phys. Geog., 30, 285-306, 2006.

Bøcker, C. A.: Using GIS for glacier volume calculations and topographic influence of the radiation balance, an example from Disko, west Greenland, Danish J. Geog., 96, 8-20, 1996.

Braithwaite, R. J. and Zhang, Y.: Sensitivity of mass balance of five Swiss glaciers to temperature changes assessed by tuning a degree-day model, J. Glaciol., 46, 7-14, 2000. 
Cui, Z.: Preliminary observations of glaciers in the Gongga Mountains, Acta Geogr. Sin., 24, 318-338, 1958 (in Chinese).

DeBeer, C. M. and Sharp, M. J.: Recent changes in glacier area and volume within the Southern Canadian Cordillera, Ann. Glaciol., 46, 215-221, 2007.

DeBeer, C. M. and Sharp, M. J.: Topographic influences on recent changes of very small glaciers in the Monashee Mountains, British Columbia, Canada, J. Glaciol., 55, 691-700, 2009.

Fujita, K.: Effect of precipitation seasonality on climatic sensitivity of glacier mass balance, Earth Planet. Sci. Lett., 276, 14-19, 2008.

Fujita, K. and Ageta, Y.: Effect of summer accumulation on glacier mass balance on the Tibetan Plateau revealed by mass-balance model, J. Glaciol., 46, 244-252, 2000.

Gao, S. and Peng, J.: The climate features in the Gongga Mountain, in: Glaciers and environment in the Qinghai-Xizang(Tibet) Plateau(I), edited by: Xie, Z. andKotlyakov, V. M., Chinese Academy of Sciences, Science Press, Beijing, 29-38, 1994.

Greuell, W. and Smeets, P.: Variations with elevation in the surface energy balance on the Pasterze (Austria), J. Geophys. Res., 106, 31717-31727, 2001.

Guo, C., Bo, M., Ji, Z., and Mao, L.: The transfer model between the Xi' an 80 and WGS- 84 coordinate systems, Northeast Surv. Map., 25, 34-36, 2002 (in Chinese with English abstract).

Haeberli, W. and Beniston, M.: Climate Change and Its Impacts on Glaciers and Permafrost in the Alps, Ambio, 27, 258-265, 1998.

Hall, D. K., Ormsby, J. P., Bindschadler, R. A., and Siddalingaiah, H.: Characterization of snow and ice reflectance zones on glaciers using Landsat Thematic Mapper data, Ann. Glaciol., 9, 104-109, 1987.

Hall, D. K., Bayr, K. J., Schoner, W., Bindschadler, R. A., and Chien, J. Y. L.: Consideration of the errors inherent in mapping historical glacier positions in Austria from the ground and space (1893-2001), Remote Sens. Environ., 86, 566-77, 2003.

He, Y., Zhang, Z., Yao, T., Chen, T., Pang, H., and Zhang, D.: Modern changes of the climate and glaciers in China's monsoon temperate-glacier region, Acta Geogr. Sin., 589, 550-558, 2003 (in Chinese with English abstract).

He, Y., Li, Z., Yang, X., Jia, W., He, X., Song, B., Zhang, N., and Liu, Q.: Changes of the Hailuogou Glacier, Mt. Gongga, China, against the background of global warming in the last several decades, J. China Univ. Geosci., 19, 271-281, 2008.

Heim, A.: The glaciation and solifluction of Minya Gongkar, The Geogr. J., 87, 444-454, 1936.

Jóhannesson, T., Raymond, C., and Waddington, E.: Time-sacle for adjustment of glaciers to changes in mass balance, J. Glaciol., 35, 355-369, 1989.

Jones, P. D., New, M., Parker, D. E., Martin, S., and Rigor, I. G.: Surface air temperature and its changes over the past 150 years, Rev. Geophys., 37, 173-199, 1999.

Kääb, A.: Combination of SRTM3 and repeat ASTER data for deriving alpine glacier flow velocities in the Bhutan Himalaya, Remote Sens. Environ., 94, 463-474, 2005.

Kang, E., Shen, Y., Li, X., Liu, C., Xie, Z., Li, P., Wang, J., Che, T., and $\mathrm{Wu}, \mathrm{L}$.: Assessment of the glacier and snow water resources in China, A Report to the Ministry of Water Resources of China, CAREERI/CAS, Lanzhou, 2004 (in Chinese).

Kargel, J. S., Abrams, M. J., Bishop, M. P., Bush, A., Hamilton, G., Jiskoot, H., Kääb, A., Kieffer, H. H., Lee, E. M., Paul, F., Rau, F.,
Raup, B., Shroder, J. F., Soltesz, D., Stainforth, D., Stearns, L., and Wessels, R.: Multispectral imaging contributions to global land ice measurements from space, Remote Sens. Environ., 99, 187-219, 2005.

Kaser, G., Cogley, J. G., Dyurgerov, M. B., Meier, M. F., and Ohmura, A.: Mass balance of glaciers and ice caps: consensus estimates for 1961-2004, Geophys. Res. Lett., 33, L19501, doi:10.1029/2006GL027511, 2006.

Khromova, T. E., Dyurgerov, M. B., and Barry, R. G.: Late twentieth century changes in glacier extent in the Ak-shirak Range, Central Asia, determined from historical data and ASTER imagery, Geophys. Res. Lett., 30, 1863, doi:10.1029/2003GL017233, 2003.

Larsen, C. F., Motyka, R. J., Arendt, A. A., Echelmeyer, K. A., and Geissler, P. E.: Glacier changes in southeast Alaska and northwest British Columbia and contribution to sea level rise, J. Geophys. Res., 112, F01007, doi:10.1029/2006JF000586, 2007.

Li, J.: Glacier in Hengduan Mountains, Science Press, Beijing, 282 pp., 1996 (in Chinese).

Li, Z., Sun, W. and Zeng, Q.: Measurements of Glacier Variation in the Tibetan Plateau Using Landsat Data, Remote Sens. Environ., 63, 258-264, 1998.

Li, X., Cheng, G., Jin, H., Kang, E., Che, T., Jin, R., Wu, L., Nan, Z., Wang, J., and Shen, Y.: Cryospheric change in China, Global Planet. Change, 62, 210-218, 2008.

Li, Z. He, Y., Yang, X., Theakstone, W., Jia, W., Pu, T., Liu, Q., He, X., Song, B., Zhang, N., Wang, S., and Du, J.: Changes of the Hailuogou glacier, Mt. Gongga, China, against the background of climate change during the Holocene, Quatern. Int., 218, 166175, 2010a.

Li, Z. He, Y., Pu, T., Jia, W., He, X., Pang, H., Zhang, N., Liu, Q., Wang, S., Zhu, G., Wang, S., Chang, L., Du, J., and Xin, H.: Changes of climate, glaciers and runoff in China's monsoonal temperate glacier region during the last several decades, Quatern. Int., 218, 13-28, 2010b.

Liu, S., Shangguan, D., Ding, Y., Han, H., Xie, C., Zhang, Y., Li, J., Wang, J., and Li, G.: Glacier changes during the past century in the Gangrigabu Mountains, Southeast Qinghai-Xizang (Tibet) Plateau, China, Ann. Glaciol., 43, 187-193, 2006.

Liu, Q., Liu, S., Zhang, Y., Wang, X., Zhang, Y., Guo, W., and $\mathrm{Xu}, \mathrm{J} .:$ Recent shrinkage and hydrological response of Hailuogou glacier, a monsoon temperate glacier on the east slope of Mount Gongga, China, J. Glaciol., 56, 215-224, 2010.

Nicholson, L. and Benn, D. I.: Calculating ice melt beneath a debris layer using meteorological data, J. Glaciol., 52, 463-470, 2006.

Oerlemans, J.: Quantifying global warming from the retreat of glaciers, Science, 264, 243-245, 1994.

Oerlemans, J.: Glaciers and Climate Change, A. A. Balkema Publishers, Rotterdam, Netherlands, 41-52, 2001.

Oerlemans, J.: Extracting a climate signal from 169 glacier records, Science, 308, 675-677, 2005.

Oerlemans, J. and Fortuin, J. P. F.: Sensitivity of glaciers and small ice caps to greenhouse warming, Science, 258, 115-117, 1992.

Ohmura, A.: Physical basis for the temperature-based melt-index method, J. Appl. Meteor.,40, 753-761, 2001.

Paul, F.: Changes in glacier area in Tyrol, Austria, between 1969 and 1992 derived from Landsat TM and Austrian glacier inventory data, Int. J. Remote Sens., 23, 787-799, 2002.

Paul, F.: The new Swiss glacier inventory 2000: application of remote sensing and GIS, Ph.D. thesis, University of Zurich, Zurish, 
Switzerland 2004, 2007.

Paul, F. and Andreassen, L. M.: A new glacier inventory for the Svartisen region, Norway, from Landsat ETM+ data: challenges and change assessment, J. Glaciol., 55, 607-618, 2009.

Paul, F. and Kääb, A.: Perspectives on the production of a glacier inventory from multispectral satellite data in Arctic Canada: Cumberland Peninsula, Baffin Island, Ann. Glaciol., 42, 59-66, 2005.

Paul, F., Kääb, A., Maisch, M., Kellenberger, T., and Haeberli, W.: The new remote-sensing-derived Swiss glacier inventory: I. Methods, Ann. Glaciol., 34, 355-361, 2002.

Paul, F., Kääb, A., Maisch, M., Kellenberger, T., and Haeberli, W.: Rapid disintegration of Alpine glaciers observed with satellite data, Geophys. Res. Lett., 31, L21402, doi:10.1029/2004GL020816, 2004.

Pelto, M. S. and Hedlund, C.: Terminus behavior and response time of North Cascade glaciers, Washington USA, J. Glaciol., 47, 497-506, 2001.

Porter, S. C.: Pattern and forcing of Northern Hemisphere glacier variations during the last millennium, Quatern. Int., 26, 27-48, 1986.

$\mathrm{Pu}$, J. (Ed.): Glacier inventory of China VIII. The Changjiang (Yangtze) River drainage basin. Gansu Culture Publishing house, Academia Sinica, Lanzhou Institute of Glaciology and Geocryology, Lanzhou, 142 pp., 1994 (in Chinese).

Racoviteanu, A. E., Arnaud, Y., Williams, M. W., and Ordoñez, J.: Decadal changes in glacier parameters in the Cordillera Blanca, Peru, derived from remote sensing, J. Glaciol., 54, 499-510, 2008.

Raup, B., Kääb, A., Kargel, J., Bishop, M., Hamilton, G., Lee, E., Paul, F., Rau, F., Soltesz, D., Khalsa, S., Beedle, M., and Helm, C.: Remote sensing and GIS technology in the Global Land Ice Measurements from Space (GLIMS) Project, Comput. Geosci., 33, 104-125, 2007.

Schiefer, E., Menounos, B., and Wheate, R.: Recent volume loss of British Columbia glaciers, Canada, Geophys. Res. Lett., 34, L16503, doi:10.1029/2007GL030780, 2007.

Shangguan, D., Liu, S., Ding, Y., Ding, L., Xiong, L., Cai, D., Li, G., Lu, A., Zhang, Q., and Zhang, Y.: Monitoring the glacier changes in the Muztag Ata and Konggur Mountains, East Pamirs, based on Chinese Glacier Inventory and recent satellite imagery, Ann. Glaciol., 43, 79-85, 2006.

Shangguan, D., Liu, S., Ding, Y., Li, J., Zhang, Y., Ding, L., Wang, Z., Xie, C., and Li, G.: Glacier changes in the West Kunlun Shan from 1970 to 2001 derived from Landsat TM/ETM+ and Chinese glacier inventory data, Ann. Glaciol., 46, 204-208, 2007.

Shangguan, D., Liu, S., Ding, L. Zhang, S., Li, G., Zhang, Y., and Li, J.: Variation of Glaciers in the Western Range of Tibetan Plateau during Nyainqêntanglha 1970-2000, J. Glaciol. Geocryol., 30, 204-210, 2008.

Shangguan, D., Liu, S., Ding, Y., Ding, L., Xu, J., and Li, J.: Glacier changes during the last forty years in the Tarim Interior River basin, northwest China, Prog. Nat. Sci., 19, 727-732, 2009.

Shi, Y. (Ed.): An introduction to the glaciers in China contents, Science Press, Beijing, 16-17, 1988.

Shi, Y. (Eds): Concise Glacier Inventory of Chinese, Shanghai Popolar Science Press, Shanghai, 205 pp., 2008.
Shi, Y. and Liu, S.: Estimation on the response of glaciers in China to the global warming in the 21 st century, Chin. Sci. Bull., 45, 668-672, 2000.

Shi, Y., Liu, C. H., and Kang, E. S.: The glacier inventory of China, Ann. Glaciol., 50, 1-4, 2009.

$\mathrm{Su}, \mathrm{Z}$. and Shi, Y.: Response of monsoonal temperate glaciers in China to global warming since the Little Ice Age, J. Glaciol. Geocryol., 22, 223-229, 2000 (in Chinese with English abstract).

$\mathrm{Su}, \mathrm{Z}$. and Shi, Y.: Response of monsoonal temperate glaciers to global warming since the Little Ice Age, Quatern. Int., 97-98, 123-131, 2002.

Su, Z., Liu, S., Wang, N., and Shi, A.: Recent fluctuation of glaciers in the Gongga Mountains, Ann. Glaciol., 16, 163-167, 1992.

Su, Z., Liang, D., and Hong, M.: Developing Conditions, Amounts and Distributions of glaciers in Gongga Mountains, J. Glaciol Geocryol., 15, 551-558, 1993 (in Chinese, with English abstract).

Su, Z., Song, G., and Cao, Z.: Maritime characteristics of Hailuogou Glacier in the Gongga Mountains, J. Glaciol. Geocryol., 18, 5159, 1996 (in Chinese, with English abstract).

Svoboda, F. and Paul, F.: A new glacier inventory on Southern Baffin Island, Canada, from ASTER data: II. Data analysis, glacier change and applications, Ann. Glaciol., 50, 11-21, 2009.

Thompson, L. G., Yao, T., Mosley-Thompson, E., Davis, M. E., Henderson, K., and Lin, P.: A high-resolution millennial record of the South Asian Monsoon from Himalayan ice cores, Science, 289, 1916-1919, 2000.

UNEP: Global outlook for ice and snow, UNEP, Birkeland, Norway, 235 pp., 2007.

Wang, J., Wang, J., and Lu, C.: Problem of coordinate transformation between WGS-84 and BEIJING 54, J. Geod. Geodyn., 23, 70-73, 2003 (in Chinese with English abstract).

Wang, N. and Zhang, X.: Mountain glacier fluctuations and climatic change during the last 100 years, J. Glaciol. Geocryol., 14, 242 251, 1992 (in Chinese with English abstract).

Xie, Z., Su, Z., Shen, Y., and Feng, Q.: Mass balance and water exchange of Hailuoguo glacier in Mountains Gongga and their influence on glacial melt runoff, J. Glaciol. Geocryol., 23, 7-15, 2001 (in Chinese with English abstract).

Yao, T., Wang, Y., Liu, S., Pu, J., Shen, Y. and Lu, A.: Recent glacial retreat in High Asia in China and its impact on water resource in Northwest China, Science in China Ser. D Earth Sciences, 47, 1065-1075, 2004.

Ye, Q., Kang, S., Chen, F., and Wang, J.: Monitoring glacier variations on Geladandong Mountains, Central Tibetan Plateau, from 1969 to 2002 using remote sensing and GIS technologies, J. Glaciol., 52, 537-545, 2006.

Zhang, Y., Fujita, K., Liu, S., Liu, Q., and Wang, X.: Multidecadal ice-velocity and elevation changes of a monsoonal maritime glacier: Hailuogou glacier, China, J. Glaciol., 56, 65-74, 2010.

Zhang, Y., Fujita, K., Liu, S., Liu, Q., and Nuimura, T.: Distribution of debris thickness and its effect on ice melt at Hailuogou glacier, southeastern Tibetan Plateau, using in situ surveys and ASTER imagery, J. Glaciol., 57, 1147-1156, 2011. 